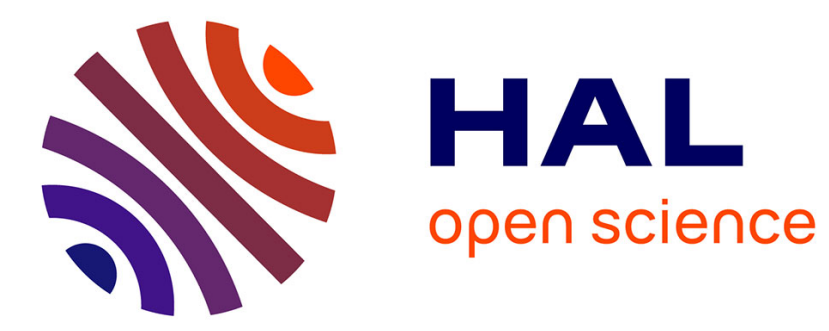

\title{
Chemo-hydro-mechanical coupling in annulus fibrosus tissue
}

\author{
Adrien Baldit, Dominique Ambard, Fabien Cherblanc, Pascale Royer
}

\section{To cite this version:}

Adrien Baldit, Dominique Ambard, Fabien Cherblanc, Pascale Royer. Chemo-hydro-mechanical coupling in annulus fibrosus tissue. 18th Congress of the European Society of Biomechanics, Jul 2012, Portugal. pp.1. hal-00726741

\section{HAL Id: hal-00726741 https://hal.science/hal-00726741}

Submitted on 18 Sep 2012

HAL is a multi-disciplinary open access archive for the deposit and dissemination of scientific research documents, whether they are published or not. The documents may come from teaching and research institutions in France or abroad, or from public or private research centers.
L'archive ouverte pluridisciplinaire HAL, est destinée au dépôt et à la diffusion de documents scientifiques de niveau recherche, publiés ou non, émanant des établissements d'enseignement et de recherche français ou étrangers, des laboratoires publics ou privés. 


\title{
CHEMO-HYDRO-MECHANICAL COUPLING IN ANNULUS FIBROSUS TISSUE
}

\author{
Adrien Baldit, Dominique Ambard, Fabien Cherblanc, Pascale Royer \\ Laboratoire de Mécanique et Génie Civil (LMGC), Université de Montpellier 2, CNRS, France
}

\section{State of the art}

Intervertebral disc (IVD) is a highly specialized element of the spine that provides flexibility and dissipative capacities. When mechanical loads are transmitted along the spine, it mainly supports compression and bending stresses. This results in a hydrostatic excessive pressure in the central nucleus pulposus and generates circumferential tensile stresses in the surrounding annulus fibrosus. To hold these large circumferential strains, the annulus tissue is a composite material made of oriented structures of collagen fibres embedded in a highly hydrated matrix [Frijns, 1997 ; Iatridis, 2005].

Thus, the IVD tissues can be assimilated to porous media where fluid flows play a major role in the macroscopic mechanical behaviour, issue of main importance when dealing with cell nutrition processes [Magnier, 2009; Huyghe, 1997].

\section{Materials and methods}

A custom test machine has been designed, composed of a tensile test machine, a bath and two microscopes oriented perpendicularly to the tensile direction (Fig. 1). It permits to carry out ex situ conditioning, cyclic and relaxing tests, while observing simultaneously the fibrous and lamellae planes. The material is lumbar discs harvested from cadaver of a domestic pig.

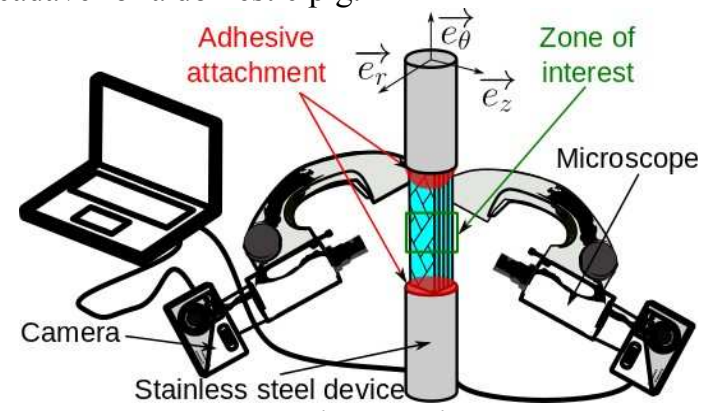

Figure 1: Experimental principle.

Thanks to the thermo-regulated bath filled with physiological solution, in vivo conditions are imposed. Furthermore, salinity and $\mathrm{pH}$ are controlled allowing characterizing the influence of environment.

Cameras images size is $1600 \times 1200$ pixels with a resolution of $2.8 \mu \mathrm{m} / \mathrm{pixel}$. Digital image correlation (DIC) is used to compute the local surface displacement and strain in both planes [Wattrisse, 2001] (Fig. 2).

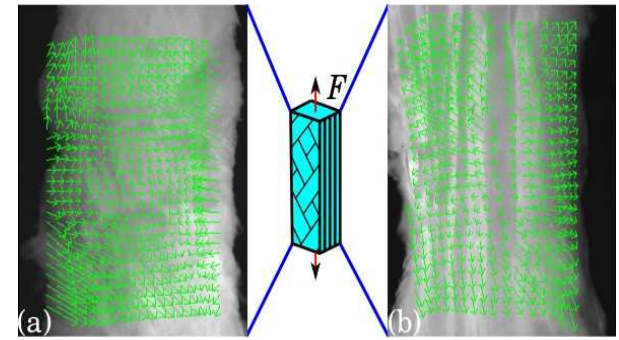

Figure 2: Displacement field: a) fibrous plane, b) lamellae plane.

We obtain roughly 375 measurements points which is relatively large compared to the optical methods classically used [Bruehlmann, 2004; Ambard, 2009].

\section{Conclusion and outlooks}

On stress-strain curves, a strong non-linear behaviour with hysteresis is observed on each cycle in agreement with the essential dissipative function of intervertebral discs. DIC results highlight shrinkage in the plane of fibres and swelling in the plane of lamellae, leading to Poisson's ratios about 0.9 and negative respectively. This anisotropic behaviour should be governed by the reorientation of fibres along the loading direction [Ambard, 2009]. Actually, shrinkage observed in fibrous plane induced an overpressure inside sample which discharges in the transverse direction, generating swelling in lamellae plane. This transfer generates fluid flows inside the porous matrix which induce viscous effects accounting for hysteresis.

Concerning the environment regulation, the mechanical stresses and strains are directly impacted by salinity variations. However, the accurate identification of diffusive and osmotic characteristics required a numerical model. Consequently, a 3-D Finite Element Model is currently under development including an anisotropic poro-elastic model in large strains [Malandrino, 2011] coupled to ions diffusions.

\section{References}

Ambard et al, Ann Biomed Eng, 37:2256-2265 2009.

Bruehlmann et al, J Biomech, 37:223-231, 2004.

Frijns et al, Int J Eng Sci, 35:1419-1429, 1997.

Huyghe et al, Int J Eng ScL, 35:793-802, 1997.

Iatridis et al, J Biomech, 38:557-565, 2005.

Magnier et al, J Biomech, 42:100-108, 2009.

Malandrino et al, Plos Comp Biol, 7, 2011.

Wattrisse et al, Exp Mech, 41:29-39, 2001. 